Kalliopi Dani

\title{
Community Collective Marks: \\ Status, Scope and Rivals in the European Signs Landscape
}




Universität
Ungsburg $\begin{aligned} & \text { THECHNISCHE GEOTAT } \\ & \text { WNASHINGTON } \\ & \text { UNIVERSITY }\end{aligned}$


Kalliopi Dani

\section{Community Collective Marks: Status, Scope and Rivals in the European Signs Landscape}


Die Deutsche Nationalbibliothek lists this publication in the Deutsche Nationalbibliografie; detailed bibliographic data is available in the Internet at http://dnb.d-nb.de

at.: Munich, Munich Intellectual Property Law Center, Thesis "Master of Laws in Intellectual Property (LL.M. IP)", 2013

ISBN: HB 978-3-8487-1605-O ePDF $\quad 978-3-8452-5646-7$

\section{British Library Cataloguing-in-Publication Data}

A catalogue record for this book is available from the British Library.

ISBN: HB $\quad 978-3-8487-1605-0$

\section{Library of Congress Cataloging-in-Publication Data}

Dani, Kalliopi

Community Collective Marks: Status, Scope and Rivals in the European Signs Landscape

Kalliopi Dani

$68 \mathrm{p}$.

Includes bibliographic references.

ISBN

$$
\text { 978-3-8487-1605-0 }
$$

\section{Edition 2014}

๑ Nomos Verlagsgesellschaft, Baden-Baden, Germany 2014. Printed and bound in Germany.

This work is subject to copyright. All rights reserved. No part of this publication may be reproduced or transmitted in any form or by any means, electronic or mechanical, including photocopying, re-cording, or any information storage or retrieval system, without prior permission in writing from the publishers. Under $\S 54$ of the German Copyright Law where copies are made for other than private use a fee is payable to "Verwertungsgesellschaft Wort", Munich.

No responsibility for loss caused to any individual or organization acting on or refraining from action as a result of the material in this publication can be accepted by Nomos or the autor(s)/editor(s). 